\title{
Map Collections and the Internet: Some Ideas about Various Online Map Services, Based on the ETH Map Collection in Zürich
}

\author{
by JÜRG BÜHLER
}

\section{MAP COLLECTIONS ON THE INTERNET - WHY?}

The Internet enables a map collection to be easily available to the general public. There are three different categories of information that can be provided:

1. General information about the map collection (e.g. opening hours, terms and conditions, user support, workspaces)

2. Search tools for maps, such as the library OPAC, index sheets for map series, map catalogues on the Internet

3. Access to in-house and external digital products such as a digital map archive, thematic virtual map libraries, links to gazetteers, links to maps, bibliographies, courses and tutorials.

The Internet allows worldwide usage of map libraries. It is well suited for public relations and therefore important for today's map libraries.

How can we develop and maintain a Web site? Usually there is no Webmaster available for map librarians. We have to do the work ourselves, including:

- Creating a Web site

- Finding useful links and integrating them in the Web site

- Digitizing our holdings for a digital archive or a thematic index

The map librarians have to learn how to create web sites using HTML. They have to learn how to navigate efficiently on the Web to find useful links for their own Web site. In addition, it is helpful to be creative using graphics in 
developing Web sites. This means more work and additional training and education.

On the other hand, we can profit from the work of our colleagues, for example by copying their index sheets or lists, selecting links from their Web sites or by consulting them. Communication between colleagues is helpful in developing and maintaining a useful Web site. The ETH-Bibliothek map site can illustrate some of the possible map services on the Internet.

\section{How to Find THE HomePage Of THE MAP COLLECTION}

The site can be located by:

- Entering the exact Internet address

- Going to the homepage of the library and selecting „maps“ or „map collection"

- Searching on Internet map machines for the „Map Collection“ or going to addresses like Oddens' Bookmarks ${ }^{1}$ or The World of Maps ${ }^{2}$.

\section{THE HOMEPAge OF THE MAP COLLECTION ${ }^{3}$}

The homepage introduces the services and the collections.

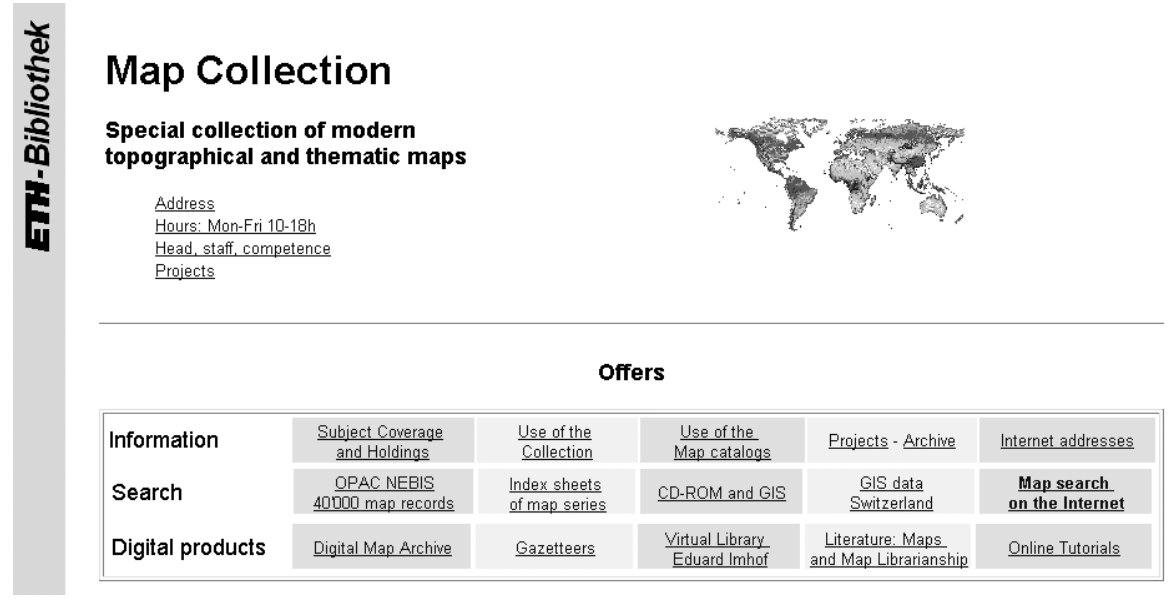


The services and collections can be divided into three levels:

1. Information

2. Search tools

3. Electronic products

\section{Level 1: Information}

\begin{tabular}{|c|c|c|c|c|c|}
\hline Information & $\frac{\text { Subject Coverage }}{\text { and Holdings }}$ & $\frac{\text { Use of the }}{\text { Collection }}$ & $\frac{\text { Use of the }}{\text { Map catalogs }}$ & Projects - Archive & Internet addresses \\
\hline
\end{tabular}

\section{a) Information about the Map Collection and how to Use it:}

This lists available maps, people to contact, address, opening hours, terms and conditions, available workspace.

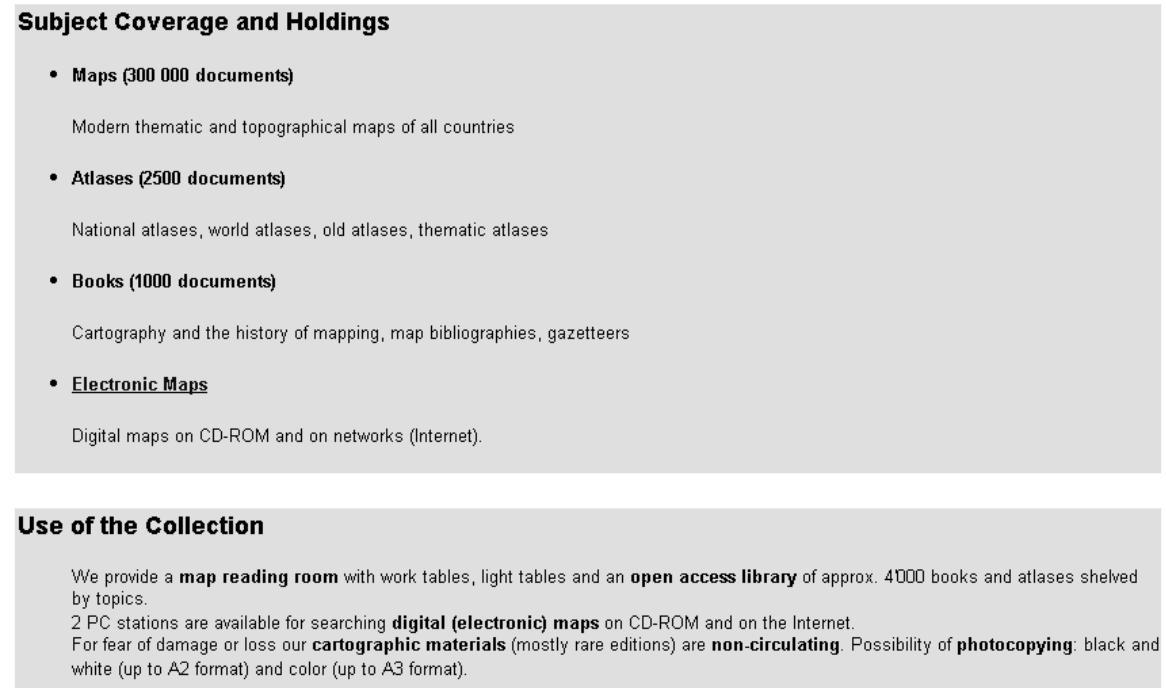

\section{Use of the Collection}

We provide a map reading room with work tables, light tables and an open access library of approx. 4000 books and atlases shelved by topics.

$2 \mathrm{PC}$ stations are available for searching digital (electronic) maps on CD-ROM and on the Internet.

For fear of damage or loss our cartographic materials (mostly rare editions) are non-circulating. Possibility of photocopying: black and white (up to $\mathrm{A} 2$ format) and color (up to $\mathrm{A} 3$ format).

A link takes you to examples of digital maps covering our subject area. ${ }^{4}$ 
Map Collections and the Internet: Some Ideas about Various Online Map Services, Based on the ETH Map Collection in Zürich

b) How to Use the Catalogue

The catalog help offers the following facilities:

- Access to the WebOPAC

- Search strategies

- Subject search

- Free text search

- Browse search

- Order number search

Level 2: Online Catalog and Search Tools

\begin{tabular}{|c|c|c|c|c|}
\hline ar & $\begin{array}{c}\text { OPAC NEBIS } \\
40000 \text { map records }\end{array}$ & $\frac{\text { Index sheets }}{\text { of map series }}$ & CD-ROM and $\mathrm{C}$ & $\begin{array}{l}\text { Maps search } \\
\text { on the Internet }\end{array}$ \\
\hline
\end{tabular}

Maps can be searched in:

a) Library online catalog (NEBIS-WebOPAC),

b) an index sheet of the map series,

c) CD-ROM and GIS data holding lists

d) Internet search tool such as the World of Maps.

a) Online Catalog NEBIS (Network of Libraries) ${ }^{6}$

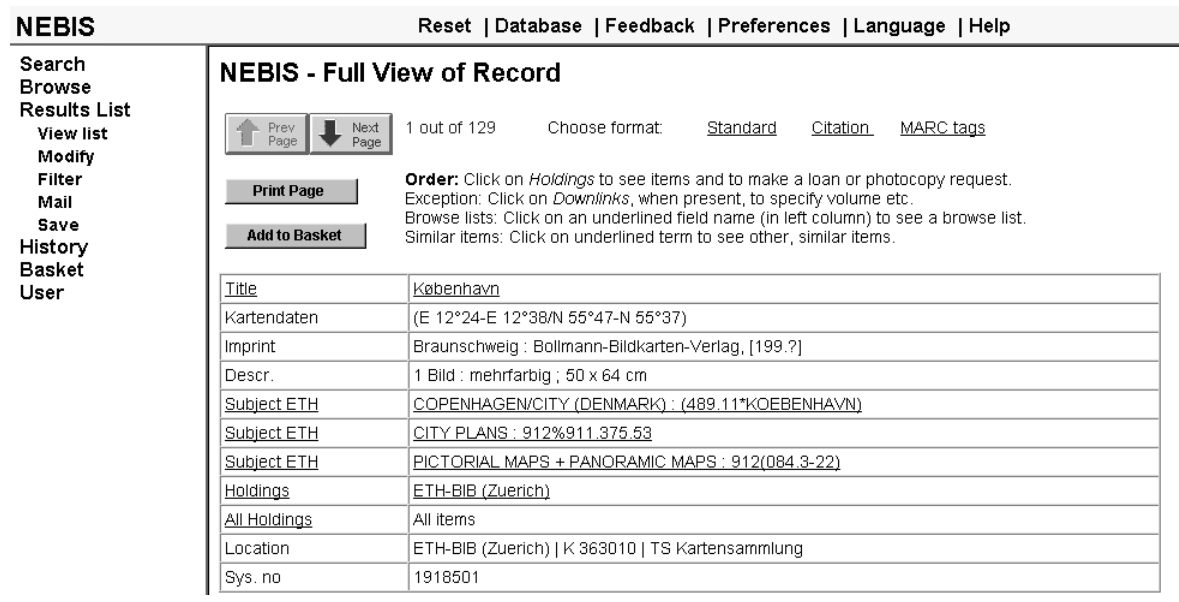


NEBIS comprises over 60 libraries. It contains holdings of the map series and atlases as well as the monographs in the ETH map collection. In NEBIS there are 40,000 records representing 300,000 maps.

\section{b) The Indexes of Map Series ${ }^{7}$}

Sheets of the map series are not recorded in NEBIS-WebOPAC. To find specific map sheets you have to go to the index of a map series. Once a map series is displayed, you can click on the index map to select the desired sheet number, and you can see a list of sheets with different editions. Wolfgang Crom (Berlin) presented this idea on a workshop in January 1999, which is easy to reproduce and also convenient for small map collections (see also Crom, 1999).

\section{Landeskarte der Schweiz 1:100 000}

Kartenbestände (Liste der Kartenblätter)

Blattübersicht

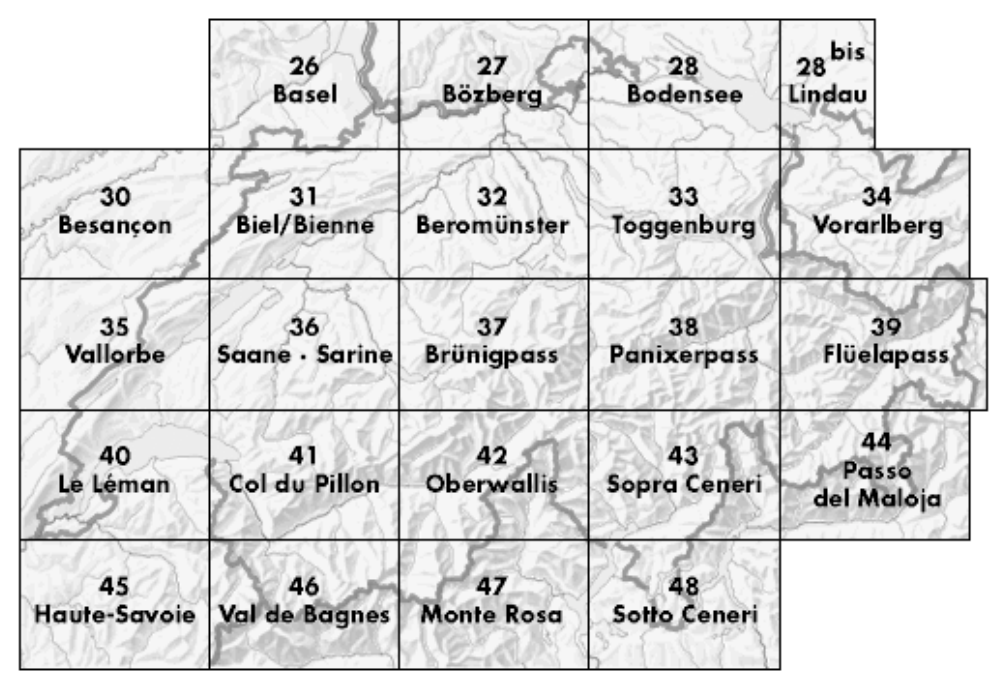


Map Collections and the Internet: Some Ideas about Various Online Map Services, Based on the ETH Map Collection in Zürich

\section{Landeskarte der Schweiz 1:100 000}

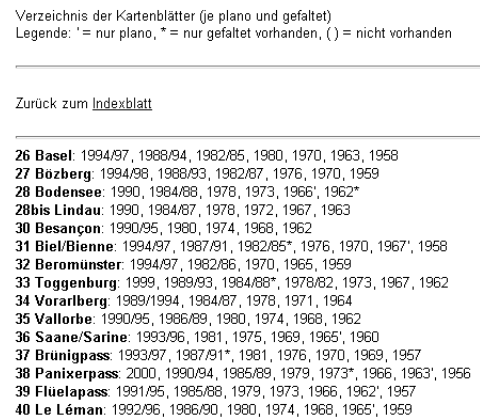

For a map collection with large holdings of map series it is recommended to use the professional software product TOPORAMA. It is user-friendly and has the map serial control function. TOPORAMA works with the software ArcView and requires an Internet map server from ESRI.

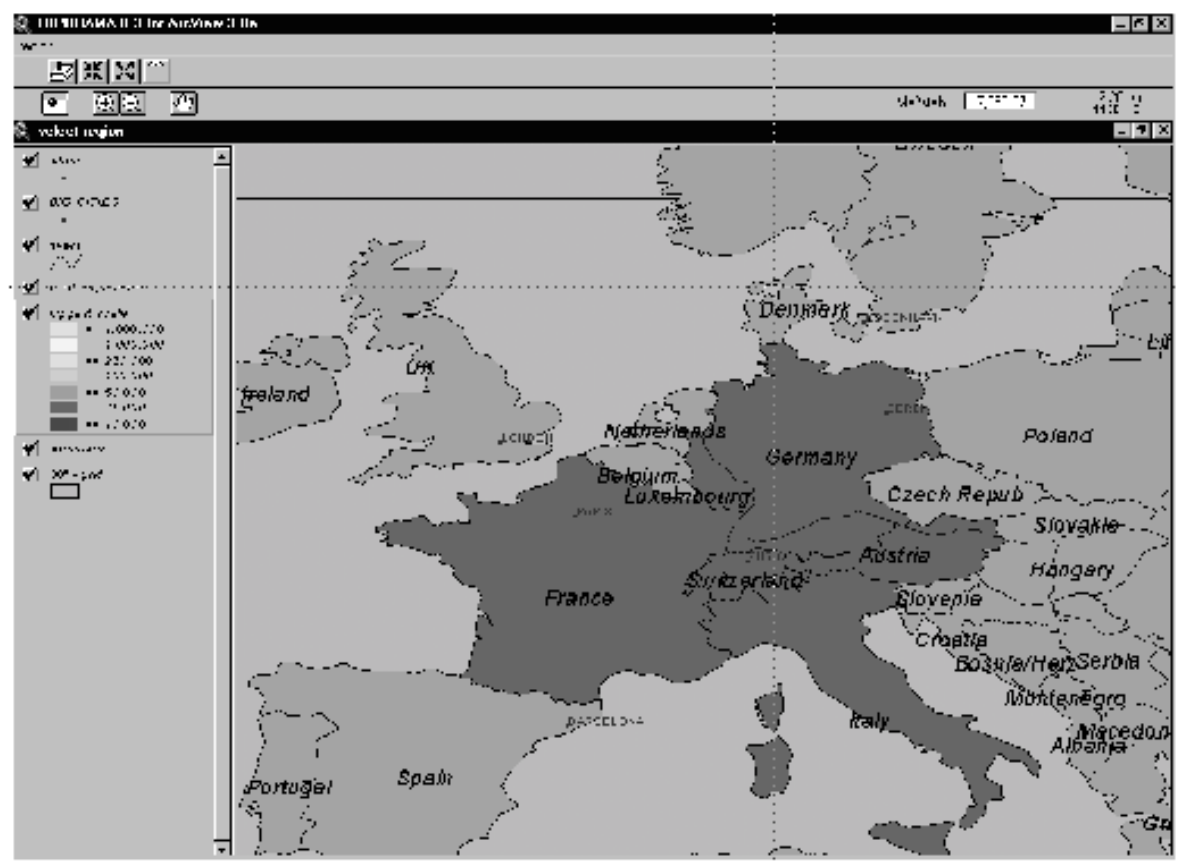

TOPORAMA: An integrated, interactive search net for map sheets worldwide. By clicking on an area of the index the desired map sheet can be obtained. 
c) $C D-R O M s^{8}$

The Web site contains a list of over $100 \mathrm{CD}$-ROMs with digital maps, spatial data and GIS products. They can be viewed on three large screen workstations in the map library. Examples:

- Switzerland: Country map 1:100,000/50,000, Digital Atlas of Switzerland, GIS „Gewässer“

- Europe: Mountain High Map, Centennia Geschichtsatlas, European Union

- Germany: Topographical map 1:50,000 including all federal states, atlas BR

- Global: Digital Chart of the World, Encarta-Weltatlas, Climate diagrams, Terra Forma

d) The World of Maps - Search for Maps and Mapping on the Internet ${ }^{9}$

\section{The World of Maps \\ Le Monde des Cartes \\ Die Welt der Karten}

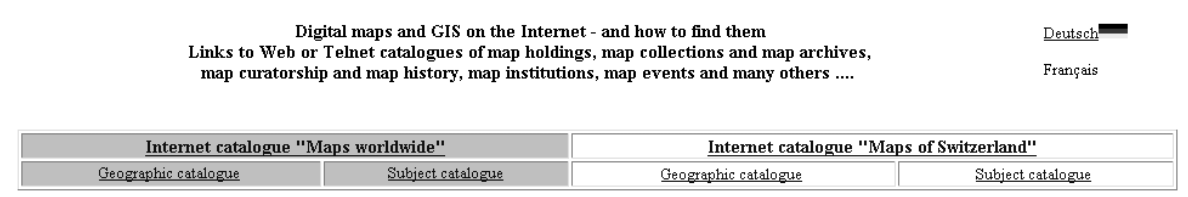

The World of Maps is an extensive link collection for maps, spatial data, map catalogues and cartographic information.

It contains a geographical and a thematic map catalogue with metadata and digital maps, 
Map Collections and the Internet: Some Ideas about Various Online Map Services, Based on the ETH Map Collection in Zürich

Metadata: Worldwide WWW map catalogues

- Oddens Bookmarks "The Fascinating World of Maps and Mapping"

Odden's Bookmarks "The Fascinating World of Maps

Odden's Bookmarks: What's New in the last month

- Digital Map Catalogue (Perry-Castaneda Library Map Collection, University of Texas)

- World - Maps of all Countries (PCL)

Alexandria Digital Library, World

Geography Guide at the Mining Company

- Maps and References, University of Iowa

Excite Maps

BUBL link: Catalogue of internet ressources

- National Geographic Map Machine

Map Quest !

WorldAtlas.com

Reliefweb Map Center: Recent events

World - Links to Maps

Active Maps World-W Wide

Map Library, Berkeley: Internet Resources in Maps and Cartography

- ArcDataOnLine Browser: GIS data in the Internet

A World of Maps: Mail order of maps

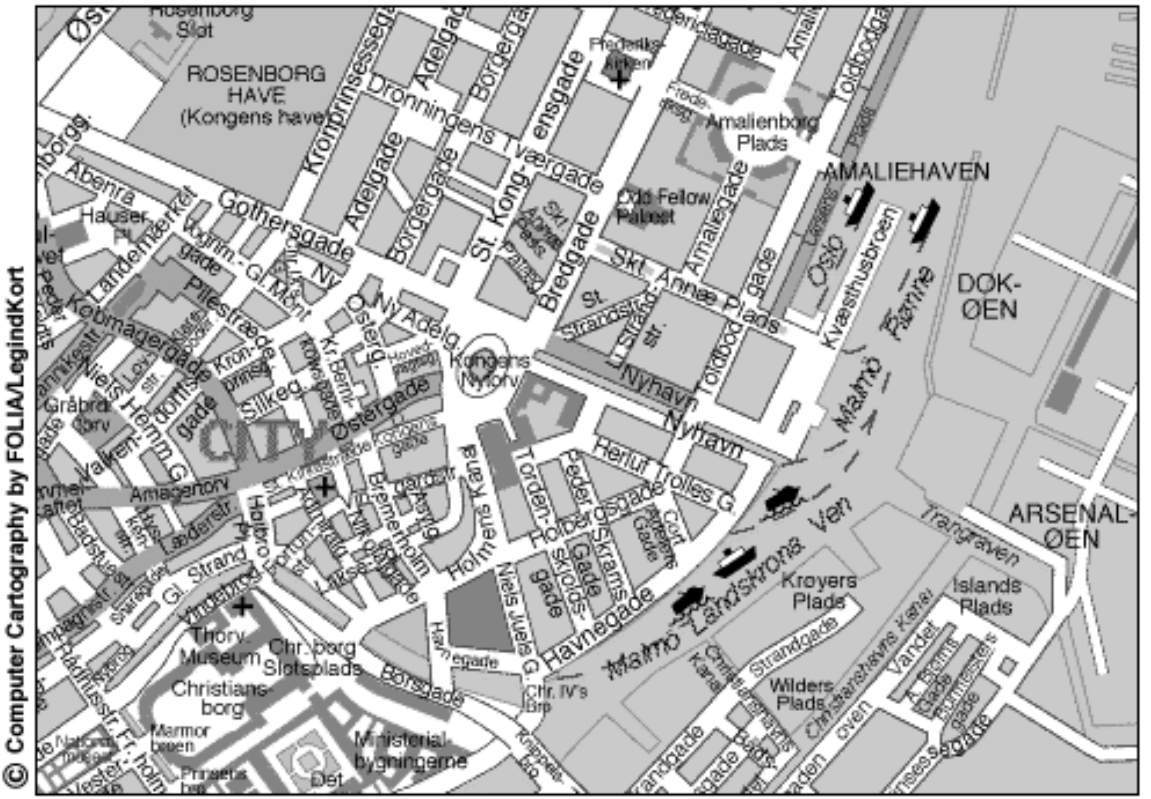

and numerous links to Web pages in cartography and map librarianship:

\begin{tabular}{|c|c|c|c|c|c|}
\hline$\frac{\text { Search ways for maps }}{\text { on Intemet }}$ & $\begin{array}{l}\frac{\text { Map libraries }}{\text { and map archives }} \\
\text { worldwide }\end{array}$ & $\frac{\text { Map curatorship }}{\text { worldwide }}$ & $\begin{array}{l}\frac{\text { Institutions, }}{\text { map research }} \\
\text { map production }\end{array}$ & $\frac{\text { Cartography and }}{\text { map history }}$ & Actual \\
\hline $\begin{array}{l}\text { Inventories of maps, } \\
\text { spatial data and GIS }\end{array}$ & $\frac{\frac{\text { Map libraties }}{\text { and map archives in }}}{\text { Switzerland }}$ & $\frac{\text { Map curatorship }}{\text { Swritzerland }}$ & Map events & Wirtual Library Eduard Imhof & $\underline{\text { The Weather today }}$ \\
\hline
\end{tabular}


- Search tools for maps on the Internet (map catalogs, search engines, OPACs)

- Map libraries and map archives

- Map librarianship, international

- Map institutions, research, producers

- Map events

- Cartography and map history

- Virtual Library „Eduard Imhof: Cartographer and Artist“

\section{Level 3: Online Products}

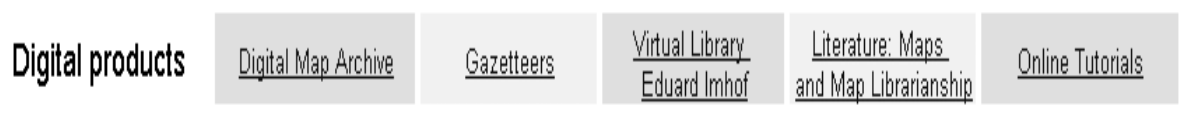

a) Digital Map Archive $e^{10}$

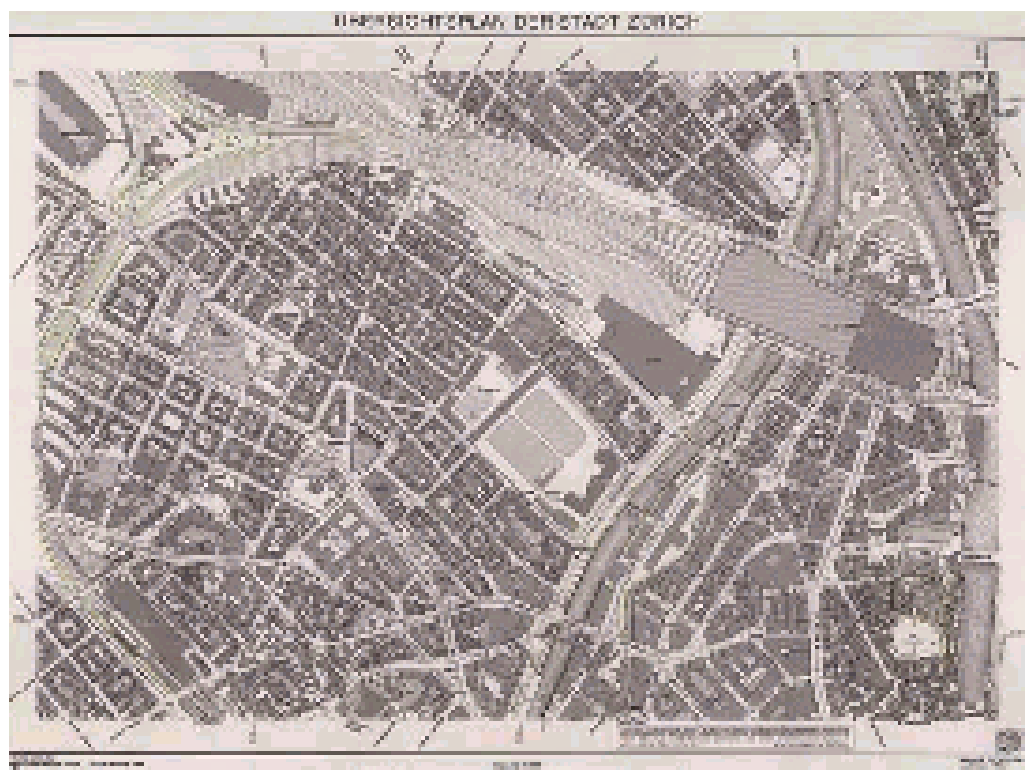

The digital map archive shows examples of the map holdings in digital form on the Internet. 
Map Collections and the Internet: Some Ideas about Various Online Map Services, Based on the ETH Map Collection in Zürich

This was created to be a map catalogue with image information. By zooming you can see a larger scale of map displayed with more cartographic and bibliographic details.

Queen Maud Range ; Axel Heiberg glacier region. - 1:1 267200 and 1:316 800. -

[London] : Royal Geographical Society, 1963. - 2 Karten auf 1 Blatt ; 21 x 29 cm, 33 x $30 \mathrm{~cm}$ Bestell-Nr.: K 671653
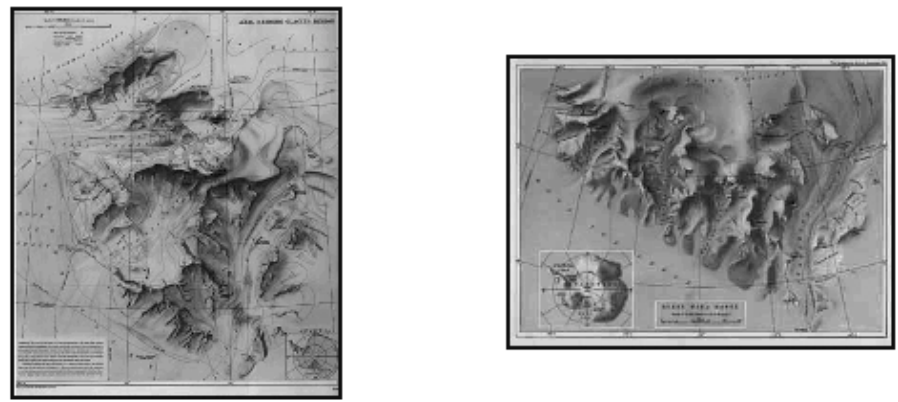

b) Registers of Local Places ${ }^{11}$

Registers of local places on the Internet are useful and popular sources.

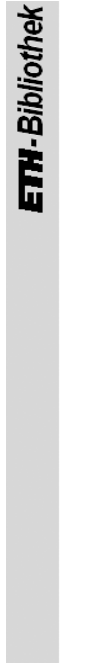

Map Collection:

Gazetteers

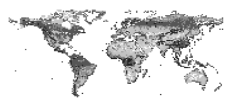

\footnotetext{
Gazetteers - worldwide

- Global Gazetteer

Getty Thesaurus of Geographic Names

- Interactive world atlas

Falk-Atlas (New world edition)

Biobliography of Gazetteers

- Odden's Bookmarks "The Fascinating World of Maps and Mapping" > Browse > Gazetteers

Regional Gazetteers

- Grossbritannien: Ordnance Survey, Gazetteer of Place Names

Grossbritannien: Interactive atlas of Great Britain (Multi Media Mapping)

- Switzerland: Interactive map of Switzerland (with gazetteer)

Switzerland: Placenames (Switzerland)

Switzerland: Geographical names of the Swiss Federal Office of Topography (database to buyd

USA: U.S. Gazetteer
} 
A „World Gazetteer" is compiled from the index of Bartholomew Times Atlas, containing more than 100,000 names worldwide and searchable by name, country, co-ordinates, etc.

We plan to connect the World Gazetteer to TOPORAMA index sheets. From the index sheet it is easy to select a local place to get to the right map sheet.

\section{c) Map Bibliographies ${ }^{12}$}

The Web site was composed for the „Groupe des Cartothécaires de LIBER“ containing extensive multilingual bibliographies in map librarianship, map history and GIS/cartography, and important gateways for map curatorship.

\begin{tabular}{|c|c|c|c|c|c|c|c|}
\hline \multicolumn{2}{|c|}{$\begin{array}{l}388_{4} \\
480^{4}\end{array}$} & \multicolumn{4}{|c|}{$\begin{array}{l}\text { Ligue des Bibliothèques Européennes de Recherche } \\
\text { Groupe des Cartothécaires de LIBER } \\
\text { Working Group for Education : Literature }\end{array}$} & & \\
\hline$\underline{\text { Literature }}$ & $\begin{array}{l}\text { Program } \\
\text { Activities }\end{array}$ & $\begin{array}{c}\mathrm{NEW!} \\
\text { Who is who } \\
\end{array}$ & $\begin{array}{l}\text { Contact, } \\
\text { Addresses }\end{array}$ & $\begin{array}{l}\text { Tutorials } \\
\text { and courses }\end{array}$ & 7 . & $\begin{array}{l}\frac{\text { LBERR Groupe des }}{\text { Cartothécaires. }} \\
\text { (a) }\end{array}$ & $\frac{\text { GadC }}{\text { Discussion Group }}$ \\
\hline
\end{tabular}

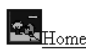

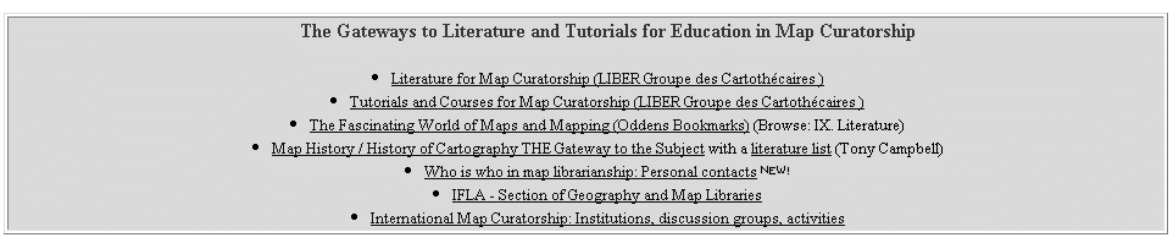

Literature for Education in Map Curatorship

- by Subject and Language

\begin{tabular}{l|l|c|c|} 
Map Curatorship & History of Cartography & $\frac{\text { GIS (Geographic Information }}{\underline{\text { Systems) }}}$ & Cartography \\
\hline
\end{tabular}

d) Tutorials and Reference Sources ${ }^{13}$

This is a collection of links to free educational programs and reference sources in cartography, GIS, geography and geo-sciences. 
Map Collections and the Internet: Some Ideas about Various Online Map Services, Based on the ETH Map Collection in Zürich

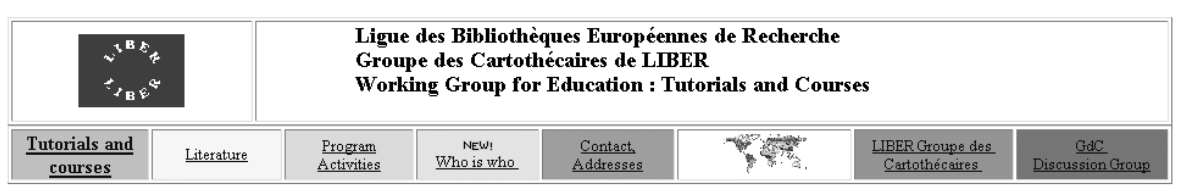

圆

GdC Campus: Tutorials and Courses

$\underline{\text { Cartography - Digital Library - GIS }-\underline{\text { Geography }} \text { - Geosciences - Internet }}$

See also: Oddens Bookmarks: Browse - XI.Miscellanous - Subcat.Educational

A. Cartography

Metadata

- The WWWVL Cartography Resources (Jeremy W. Crampton's Web Pages) NEw!

General Cartography

- 3G on W3: The Great Globe Gallery (Cartography)

- Cartographic Communication

- Cartography (Virtual Geography Department

e) Who is Who in Map Librarianship ${ }^{14}$

"Who is Who in Map Librarianship" contains useful information about map librarians and their special fields of knowledge, serving as a guide to find help for any particular problem on a personal level. A valuable tool, organized by country and subject in order to find the relevant person. 


\begin{tabular}{|c|c|c|c|c|c|c|c|}
\hline \multicolumn{2}{|c|}{ 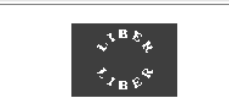 } & \multicolumn{6}{|c|}{$\begin{array}{l}\text { Ligue des Bibliothèques Européennes de Recherche } \\
\text { Groupe des Cartothécaires de LIBER - Working Group for Education } \\
\text {-Who is who- Questionaire by nation }\end{array}$} \\
\hline $\begin{array}{c}\text { NEW! } \\
\text { Who is who }\end{array}$ & $\frac{\text { Program }}{\text { Activities }}$ & $\begin{array}{l}\text { Contact. } \\
\text { Addresses }\end{array}$ & Literature & $\begin{array}{l}\text { Tutorials } \\
\text { and courses }\end{array}$ & \% & $\frac{\text { LIBER Groupe des }}{\text { Cartothécaires }}$ & $\frac{\text { GdC }}{\text { Discussion Group }}$ \\
\hline
\end{tabular}

圆

Who is Who in Map Librarianship (by nation / by subject)

Questionaire by nation

Austria - Belgium - Croatia - Denmark - Estonia - Finland - France - Germany - Ltaly - Latvia - Luxembourg - Netherlands - Norway - Poland - Portugal - Russia Spain - Sweden - Switzerland - United Kingdom - Questionaire by subject

\begin{tabular}{|c|c|}
\hline Austria: & \\
\hline $\begin{array}{l}\text { Cernajsek, Tillfried } \\
\text { Geologische Bundesanstalt } \\
\text { Postfach } 127 \\
\text { A-1031 Wien } \\
\text { Phone: }+4317125674500\end{array}$ & $\begin{array}{l}\text { german, english } \\
\text { knowledge in map curatorship in general } \\
\text { acquisition } \\
\text { aerial photographs } \\
\text { cataloguing and formatting }\end{array}$ \\
\hline
\end{tabular}

\section{f) Virtual Library Eduard Imhof - History of Cartography on Internet ${ }^{15}$}

„Virtual Library Eduard Imhof" is created from original documents of the famous cartographer. This virtual library, is an interesting product making our archival material accessible world-wide, containing over 50 web sites with close to 200 pictures divided in 11 chapters, a biographical section and a reference list of the original resource. This is a valuable Web site both for historians in cartography and the general public.

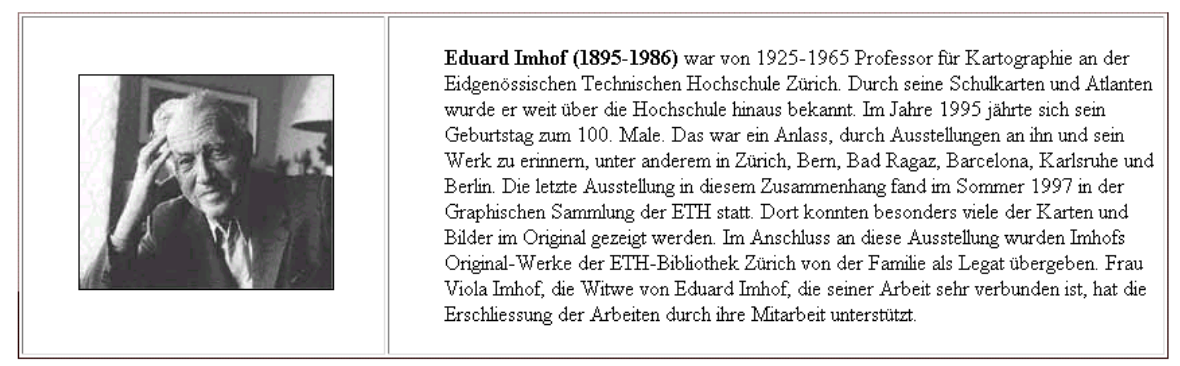


Map Collections and the Internet: Some Ideas about Various Online Map Services, Based on the ETH Map Collection in Zürich

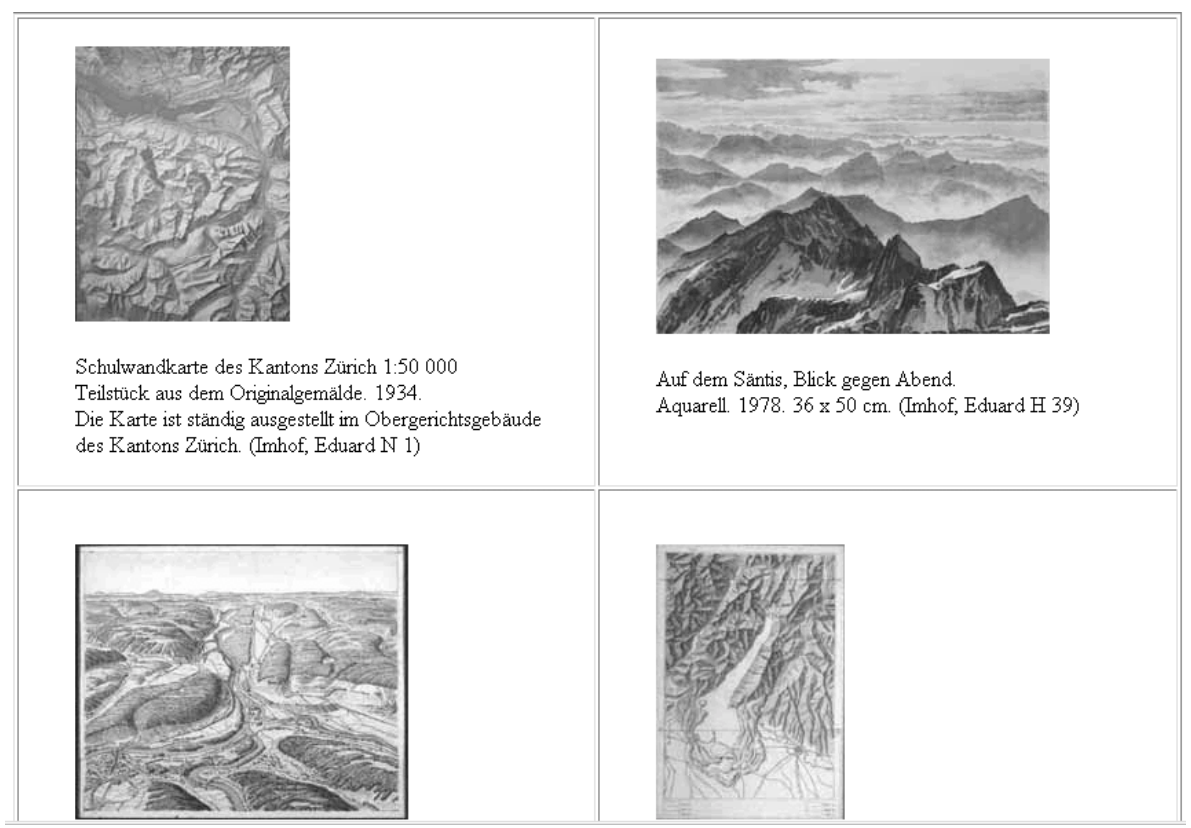

\section{CONCLUSION}

The Map Collection on Internet is an opportunity with many possibilities:

- Information about the collection

- Links to online library catalogs and GIS data

- Internet search tool for maps

- Worldwide local index

- Map index

- Digitizing in-house resources

It is a broad and demanding field and a challenge for our profession! 


\section{REFERENCES}

Crom, W. A map collection on the Internet, LIBER Quarterly 9 (1999), pp. 222227.

1 <http://oddens.geog.uuu.nl/index.html>

$2<$ http://www.maps.ethz.ch>

3 <http://www.ethbib.ethz.ch/ks/karten.html>

4 <http://www.maps.ethz.ch/digarchiv.html>

5 <http://www.ethbib.ethz.ch/ks/kartenkatalog.html>

6 <http://opac.nebis.ch:4505/ALEPH/start/nebis-ger/new>

7 <http://www.ethbib.ethz.ch/ks/karten-indexbl_e.html>

8 <http://www.ethbib.ethz.ch/ks/kart_cd_e.html>

9 <http://www.maps.ethz.ch/maps3.html>

$10<$ http://www.maps.ethz.ch/digarchiv.html>

11 <http://www.ethbib.ethz.ch/ks/kart_ortsreg.html>

$12<$ http://www.maps.ethz.ch/gdc-education2.html>

13 <http://www.maps.ethz.ch/gdc-education4.html>

14 <http://www.maps.ethz.ch/gdc-education6.html>

15 <http://www.maps.ethz.ch/imhof_engl.html> 